\title{
Sharing the Pie: Trade Unionism and Industrial Relations in Multinationals in Bangladesh
}

\author{
Monowar Hossain Mahmood \\ East West University \\ Bangladesh
}

\begin{abstract}
Using the 'convergence-divergence' thesis as the baseline for the study of industrial relations and trade union activities in multinational subsidiaries, the present study tried to investigate extent of the trade union activities and IR practices of MNCs in a developing country context, i.e. Bangladesh, as well as influence of the MNCs on trade unions and IR activities within the existing social and economic contexts. The study revealed that comparative power dominance of multinationals over the host country industrial relations actors emerge as the vital factor in employer-union bargaining process, as well as their capacity to manipulate the existing bargaining process also helped them to implement their desired practices in Bangladesh. However, multinationals were not in confronting mode at all the circumstances, but their potential lobbying power created difficulties for the employees and the trade unions to develop countervailing power in the collective bargaining process and IR activities.
\end{abstract}

Keywords: Convergence-Divergence, Bangladesh, Multinationals, Trade Unions

\section{Introduction}

Empirical studies of international human resource management (IHRM) often reveal that industrial relations practices of multinational subsidiaries face a "challenge from established home country labour and IR institutions' to comply with the local practices (Clark, and Almond, 2004; Monks, 1996; Muller-Camen, et al., 1998) and they need to adjust their IR practices according to the local circumstances. Sometimes, because of flexible and dynamic institutional arrangement, they also find less pressure to adopt their HRM and IR practices similar to local practice and are less likely to adjust their IR approach according to host country circumstances (Dickman, 1999; Edwards, and Ferner, 2002; Quintanilla, 1998). These two scenarios have developed the "divergenceconvergence" (Muller, 1998; Ferner, 2002) thesis in the area of IHRM and IR research. However, most of the studies on IR in MNCs have been conducted in developed countries where MNCs often confronted with the established institutionalised systems (Edwards, 2002; 2005). Having a good employer image, multinationals in Bangladesh supposed to be one step ahead of domestic organisations in complying with legallyspecified IR practices. Most of the domestic private sector organisations show some reluctance to recognise trade unions or handle industrial relations issues properly, and this approach has created adversarial labour-management relations at the enterprise level. 
The trade unions in the domestic private sector organisations are synonymous with illegal strikes, work stoppages and non co-operation compared to the smooth and healthy industrial relations observed in the foreign multinationals (Akkas, 1998; Hoque, 1994; Miyan, 1991; Robinson, 1996). The reasons why multinational subsidiaries observe the legally-specified IR practices may be found in the relative weak position of the trade unions in the IR legislation, the government's role in favouring multinationals, or the perceived impact of legally-defined industrial relations mechanism on the business operations in Bangladesh (Robinson, 1996; Taher, et. al., 1998; Ullah, 1989). The present study aims to investigate the 'convergence-divergence' dilemmas of the MNCs subsidiaries in Bangladesh and the underlying reasons for showing affinity to any particular polar in this respect.

In this paper, first I will try to provide a brief overview of industrial relations scenario of local organizations of Bangladesh. The second section will assess the attitude of the multinational subsidiaries towards recognition of trade unions and compliance with other legal requirements of IR practices as this area is still unknown and unearth to the researchers and policy makers. The third section will investigate the reasons for compliance or non-compliance with legal arrangements in the less institutionalised context of Bangladesh as well as direct or indirect influence of the parent companies on the IR practices of the subsidiaries. And finally we will try to identify the implicit effects of multinationals' IR practices on the local IR systems.

\section{Literature Review: Trade Unions and Industrial Relations Scenarios in Bangladesh}

In Bangladesh, the nature and role of trade unions vary from sector to sector, industry to industry, and region to region (Akkas, 1998; Khan, 1996; Robinson, 1996; Taher, et. al., 1998). Collective bargaining on pay and allowances is forbidden in the public sector (Robinson, 1996) as the government determines a single set of uniform pay scales and allowances for all the public sector enterprises (Akkas, 1998; Hoque, 1994; Miyan, 1991). Trade unions are handling only industrial conflicts and some other issues like the application of labour laws, improvement of working conditions, adoption of welfare programmes of the workers, and education and training of the workers (Akkas, 1998; Khan, 1996; Talukdar, 1997). This limited scope of collective bargaining issues forces the trade unions to develop links with the influential actor i.e. government, to achieve their goals, and therefore, industrial relations involve interaction between political parties and trade unions rather than interaction between enterprise management and worker representatives (Robinson, 1996; Ullah, 1989). The centralised structure of pay bargaining in the public sector organisations makes it difficult to link the pay with the performance, which in turn brings inefficiencies and organisations are losing their competitiveness in the long run (Akkas, 1998; Robinson, 1996).

In the private sector, all sorts of collective bargaining take place at the enterprise level between the management and the union (if more than one union then with the CBA) (Khan, 1996; Robinson, 1996). The recognition of workers' organisation for the purpose of collective bargaining depends on each employer and the strength of workers organisations' concern. In the private sector, the industrial relations process is often 
disturbed by links between private and public sector unions and the influence exerted by the latter on the former. The aggravated violence in the public sector often spills over to surrounding privately-owned factories. Guidelines for the establishment of a 'Participation Committee' in every establishment where 50 or more workers are employed, with equal numbers of workers' and employers' representatives are provided by the IRO 1969, but in practice, few enterprises have introduced 'Participation Committees', and where they have, these mechanisms reportedly served a negligible role at the plant level. Most employers perceive such participation as an encroachment of their rights and prerogatives, trade unions consider these committees as a sort of parallel organisation which may undermine their effectiveness, and believe that the functions of such committees impose only duties, obligations and responsibilities on them without any corresponding benefits and choice in the management (Khan, 1996). Due to close business-politics links in Bangladesh, the first generation employers in Bangladesh (virtually a few hundred people coming from just a few families) control and direct the economy, laws and the government as a whole (Kochanek, 1993). The silent features of present industrial relations scenario in Bangladesh are now discussed.

\section{High involvement of the Government}

One of the main features of the present industrial relations system in Bangladesh is the central role of government (Robinson, 1996; Taher, 1998). In the private sector organisations, though the legislative framework provides guidelines for settlement of industrial disputes and other bargaining issues at the plant level, government still holds the power to intervene at any time without prior consent or consultation with the aggravated parties. The IR(R)O, 1982 provided that the government may, at any time, refer any industrial disputes or workers' grievances to a conciliator or labour court for settlement of such disputes, or suggest measures for redress of such grievances. Although this demonstrates that government is irrevocably and unquestionably committed to swift and peaceful resolution of such disputes, in practice the differences in government arrangements, restrictive legal steps and improper execution of legal provisions interrupt considerably the effective use and operation of the dispute settlement methods (Alam, 1983). Ahmed and Modal (1993) convincingly demonstrated that among the government intercepted (through Arbitration) industrial disputes, nearly 89 percent were resolved through an unconditional return to work on the part of the workers rather than via an amicable solution between the parties. This mainly happened due to the coercive role of the government and relatively weak union power at the enterprise level.

Although the existing laws are applicable in both private and public sector organisations, there have also been a few labour laws specifically related to public sector. Plant level decentralised bargaining related to pay and benefits is prohibited in public sector organisations and employees' service terms and conditions differ substantially from those in the private sector. The government unilaterally determines the pay and benefits, and public sector employees enjoy comparatively better job security than their counterparts in private sector. In the public sector, the enterprise management can not terminate or transfer any trade union leader without government prior approval whereas in the private sector, employers can terminate any employee, including trade union leaders, with two months' prior notice without any further explanation. This job security provision 
influences trade union activities in the public sector organisations and trade union leaders behave politically to show alignment to the ruling political party.

\section{Politicised trade unionism}

The whole industrial relations system in Bangladesh is highly politicised in nature, and disruption often occurs due to political reasons, e.g., inter-union rivalries, political issues and token and sympathy strikes, etc. Most of the time, the problems start when unions affiliated with one party try to overthrow the existing CBA affiliated with a different party. Management in the public sector organisations rarely appears to be neutral and tends to support the union affiliated with the ruling political party (World Bank, 1996). Indeed, managers of both private and public enterprises deliberately support the unions of the ruling political party in order to seek benefits from the government. Labour leaders change unions or form new unions for higher positions and financial benefits. Private sector employers instigate the creation of new unions to restrain or to eliminate the strong unions which they do not like. Large federations linked with major political parties can be more effective in influencing government policy toward labour as well as strategies of labour union movements.

Whether or not such federations can adopt policies in the interest of workers, their choice of objectives depends on the insiders and outsiders within the leadership of those unions and federations. In critical times and matters, union members are likely to be subject to the overall policies of the respective political parties with which they are linked (Hossain et. al., 1998). Most of the structured trade unions, in practice, act as sister organisations to the various political parties, and remain useful assets in the calculus of domestic power politics. In deed, almost all TU federations have links (either temporary or permanent) with political parties, and the three largest federations i.e. Jatio Sramik League, Jatiyatabadi Sramik Dal and Jatiya Sramik Party are the labour front organisations of the three major political parties, representing around 65 percent of total unionised employees in Bangladesh (ILO, 1996:35). Political connections play an important role in raising the leadership capability and this relationship marks a turning point in broadening the sphere of political influence in hitherto uncharted territory (Akkas, 1998; Dannecker, 2000; Taher, 1999). Under such circumstances, industrial relations involve interaction between political parties (particularly the ruling party) and trade unions, rather than interaction between enterprise management and worker representatives. During the period between 1977-1991 (based on available data), about 44 percent of industrial disputes were caused by so-called political factors such as inter and intra-union rivalries, political issues of national interest and sympathetic strikes for causes of specific political parties (Mondal, 1992).

Since the collective bargaining agreements in the private sector are open-ended in duration, the timing of renegotiation becomes an important bone of contention. Employers are inclined to put off negotiating a new contract as long as possible. In a situation where union structure is weak and the unions are largely dependent on the support of activists and direct action, organising workplace activities is likely to be regarded as a better way of mobilising workers towards their target or own objectives. Having failed to do this because of power imbalances between the management and 
union leaders, the latter sought support from outside pressure groups mainly linked with the political parties.

Politicisation of trade unions may be a result of the predominance of public enterprises in industries and direct involvement of government in all the functional areas of HRM practices. Because management is centralised and collective bargaining is restricted in the public sector, trade unions are unable to pursue their objectives through the normal machinery of industrial relations, and in trying to achieve their goals, they become dependent on the political parties. In the absence of effective tripartite consultation, and the excessive government role in the labour market, trade unions (represented by SKOP) try to impose a bilateral process of negotiation with the government.

\section{Social class segregations and union-management distance}

The present industrial relations system does not facilitate the process of labourmanagement co-operation due to the behavioural and ideological characteristics of the trade unions and the employers. Employers are generally suspicious and apprehensive towards unions and are not keen to negotiate with them, thereby subsequently affecting the industrial relations system. The 'high and mighty' (Rashid, 2001:41) attitude of employers prohibits them from sitting together and negotiating with the workers. In the emerging formal private sector in Bangladesh, the owners tend to be patrimonial as a class, and try to resolve all industrial conflicts through autocratic and unilateral decisions. One reason for this predisposition could be a historically sustained in-built authoritarianism in all spheres of entrepreneurship. Certainly, the earlier dominance of the semi-feudal and large land-owners influences the attitudes of most of the industrialists of Bangladesh and their dealings with subordinates and workers (Khan, 1991). Just as the agricultural workers were treated as virtual serfs on the landed estates of Jamindars (landlords) a few decades ago, so workers in the private sector, with a few exceptions, are still dealt with by a mixture of authoritarian and paternalistic managerial practices. Trade union leaders blame the first generation employers who believe the best way to increase productivity is to force labourers to work harder and longer. Most of these employers have, in fact, failed to realise the link between improved work environment and worker productivity (Hossain, 2001). Private sector employers never declare any profits of their enterprises and do not pay any extra bonus or incentive to the employees, and by not doing so, they deprive the employees of their legal share in the organisational profits. In this situation, the absence of mutual understanding, trust, and active co-operation between workers and employers seems inevitable.

\section{Methodology}

The research objective, i.e., to investigate the 'convergence-divergence' hypothesis of in explaining the trade union and IR practices of multinational subsidiaries in a developing country context, i.e. in Bangladesh guided me more accurately towards a qualitative research strategy. While a quantitative study may identify the incidence of different IR practices at the subsidiary level, it would be less useful in gaining an understanding of the process as well as explaining why subsidiaries are adopting those practices (Whitfield and Strauss, 2000). This is partly due to the limited ability of the quantitative approaches to investigate the context as a whole (Miles and Huberman, 1994). Martin and Beaumont 
(1999) viewed quantitative research methods as relatively weaker in providing rich and valid descriptions of the HRM and IR development processes, and argued for in-depth qualitative case studies to flesh out the insights of HRM and IR determination processes in multinational subsidiaries. After considering the above concerns, I decided to conduct in-depth case studies of four multinational subsidiaries i.e., A Pharma, G Pharma, N Pharma and B Chem). We included both historical and longitudinal evidence in our case studies. The study was conducted over a period of nearly four years, from the initial pilot study to the final study and subsequent visits at the sites, and all these provided the opportunity to add a longitudinal dimension to the whole research process.

In each case, I considered the comparable sites, groups, and individuals with the same relevant characteristics or roles in the organisational context. In the main field study of the four multinational subsidiaries, we identified the Head of the Human Resources Department, one managerial employee in the Quality Control/Assurance department (similar role and hierarchical position), one non-managerial employee (shop floor production employee), and two Trade Union leaders in each organisation as the main key informants. The Head of the Human Resources Department was selected due to relevant knowledge and much involvement with the subsidiary HRM and IR practices, and possible links with headquarters regarding the parent company IR directions. Managerial employees in Quality Control were selected because of their position and work role in the production department, as well as their involvement with shop floor production employee management functions. Besides those key informants, interviews were also conducted in different departments to obtain cross-section information about the IR practices among the employees at various levels. Sometimes, participation observation method was used to collect empirical evidence from the case study organisations.

Table: 1 The Interviews in Different Organisations

\begin{tabular}{|c|c|c|c|c|c|c|}
\hline Organisations & $\begin{array}{c}\text { Interviews } \\
\text { with HRM } \\
\text { managers }\end{array}$ & $\begin{array}{l}\text { Interviews } \\
\text { with other } \\
\text { managers }\end{array}$ & $\begin{array}{l}\text { Interviews } \\
\text { with } \\
\text { managerial } \\
\text { employees }\end{array}$ & $\begin{array}{c}\text { Interviews } \\
\text { with non- } \\
\text { managerial } \\
\text { employees }\end{array}$ & $\begin{array}{c}\text { Interviews } \\
\text { with Trade } \\
\text { union } \\
\text { leaders } \\
\end{array}$ & $\begin{array}{c}\text { Total } \\
\text { interviews }\end{array}$ \\
\hline A Pharma & 4 & 3 & $\begin{array}{c}1 \text { key } \\
\text { informant, } 5 \\
\text { others }\end{array}$ & $\begin{array}{c}1 \text { key } \\
\text { informant, } 4 \\
\text { others }\end{array}$ & 4 & 22 \\
\hline G Pharma & 3 & 3 & $\begin{array}{c}1 \text { key } \\
\text { informant, } 6 \\
\text { others }\end{array}$ & $\begin{array}{c}1 \text { key } \\
\text { informant, } 4 \\
\text { others }\end{array}$ & 3 & 21 \\
\hline N Pharma & 2 & 2 & $\begin{array}{c}1 \text { key } \\
\text { informant, } 3 \\
\text { others }\end{array}$ & $\begin{array}{c}1 \text { key } \\
\text { informant, } 4 \\
\text { others }\end{array}$ & 2 & 14 \\
\hline B Chem & 3 & 4 & $\begin{array}{c}2 \text { key } \\
\text { informant, } 4 \\
\text { others }\end{array}$ & $\begin{array}{c}1 \text { key } \\
\text { informant, } 4 \\
\text { others }\end{array}$ & 4 & 22 \\
\hline Others & \multicolumn{5}{|c|}{$\begin{array}{l}3 \text { government officials, } 3 \text { HR consultants, } 3 \text { retired employees, } 4 \\
\text { academicians, } 5 \text { national trade union federation leaders }\end{array}$} & 18 \\
\hline Total & & & & & & 133 \\
\hline
\end{tabular}




\section{Findings of the Study}

The IR practices evident in multinational subsidiaries and domestically-owned private sector organisations in Bangladesh reveal marked differences in the attitudes, behaviour and policies. Multinational subsidiaries operating in Bangladesh have a positive attitude towards trade union recognition and maintaining the institutional arrangements of IR practices, and none of the case study multinationals reported any incidents of union interference in routine managerial decisions, and found no reason to resist the union activities.

\section{Attitudes toward the Trade Unions: 'Partner' not 'Antagonist'}

The parent company of B Chem advises the subsidiary to maintain local regulations in their IR practices, so the management recognises the trade union as employee representative and co-operates with employees to form trade unions at the plant level. The non-managerial employees in B Chem have formed two trade unions and elected one of them as the Collective Bargaining Agent (CBA) to negotiate pay and related issues with the management. The HR Director of B Chem stated that:

"We have two trade unions in our organisation and one acts as the collective bargaining agent in the bargaining process with management. The trade union leaders do not interfere in our management decisions. Whenever there is a need to discuss the issues with the CBA representative, we call the President and the General Secretary to come and express their opinion. We believe in fair industrial relations practices, and encourage the honest and sincere trade unionism for mutual benefits."

The HR Director of A Pharma explains the recognition of trade unions from a different viewpoint. He considered that trade union forces in Bangladesh could be used effectively for organisational development, but it depends on the attitude and sincerity of the management. He further commented:

"Multinationals in Bangladesh are doing their business in a fair way. We are giving the right amount of taxes to the government, maintaining health, safety and environmental measures properly. Headquarters asked us to observe all the legal requirements of the country properly. We deal with the trade unions within the legal framework. As long as we are fair in our activities, trade unions can not make any problems for us."

The parent company of $\mathrm{N}$ Pharma believes in trade union rights and recognises trade unions all over the world. The subsidiary is under direction to comply with all the local legal requirements. The non-managerial employees in $\mathrm{N}$ Pharma have formed one trade union which acts as the collective bargaining agent to represent them in all the unionmanagement negotiations. The HR Director of N Pharma commented on the trade union recognition that:

"We have one registered trade union comprising all the non-managerial employees of the subsidiary. Our trade union is not registered with any national 
trade union federation and we never faced any external or political influence on collective bargaining arrangement. Employees are happy with our pay and benefit package and they are not interested in other management issues."

The HR General Manager in G Pharma explained that trade unions in multinationals were not destructive, unlike those in the local organisations. He observed that trade unions were not interested in management affairs other than financial matters, and further commented:

"The main purpose of forming trade unions in Bangladesh is to realise better financial benefits. In our country, workers do not bother about working conditions, health and safety measures, or any other organisational matters. They just want money, money and money. As long as we review the pay agreements periodically and offer better financial benefits compared to other organisations, they will not make any trouble for us."

Three of the case study multinational subsidiaries, A Pharma, G Pharma, and B Chem arrange CBA elections every two years, and negotiate the pay and benefits with the CBA leaders bi-annually. N Pharma has only one trade union, but it also negotiates the pay and benefits with union officials bi-annually. Multinationals in Bangladesh face some difficulties in introducing their preferred practices without convincing the trade unions, and in $\mathrm{N}$ Pharma, for instance, management has failed to introduce individual performance related pay increments for the non-managerial unionised employees. The General Manager HR of $G$ Pharma termed the non-managerial pay issues as an 'explosive matter' and stated that he would not attempt to change anything without trade union consent. As long as he could manage the CBA leaders regarding pay issues, there would be no fear of any industrial unrest in the subsidiary.

Other than the legal provisions of trade union recognition and collective bargaining about pay and related issues, none of the multinationals showed any interest in other voluntary employee involvement schemes, such as formation of participation committees to encourage employees' involvement in management issues. In N Pharma and A Pharma, some CBA representatives are included in canteen and other welfare committees, but those voluntary initiatives seem to be tactics to avoid employee complaints rather than a means of listening to employee voices, employees revealed at the interviews. While discussing about union involvement in management, even the trade union leaders in $\mathrm{B}$ Chem complained that management never seems to find it useful to invite trade union leaders or employees to give their opinion on different issues. Most of the trade union leaders found such committees useless as they do not have any authority to execute any recommendation in the organisational context. They also expressed their concern about such initiatives as management might try to use such committees as an alternative to the CBA representatives. The CBA leaders in B Chem explained the interest of the management to form a second trade union to undermine the power of the existing union and to patronise the second one to ensure its success in CBA elections. But this management effort failed as employees realised the motives of such initiatives and 
management has now become more careful and sincere in dealing with the older trade union, CBA leaders explained.

\section{Complying with Local Regulations - A Pragmatic Adaptation}

The reason for compliance with local regulations may be that local multinational managers perceive the outcome could be to maintain continuous operations, and thus override losses through uninterrupted production in Bangladesh. Their relative profitability (Chowdhury et al., 1998) and export orientation placed the multinationals in an advantageous position to offer better pay packages compared to domestic organisations, and provide more leeway for improving pay levels on continuous basis. This sort of attitude of pragmatic adaptation observed in other countries as well when multinationals perceived their compliance more beneficial compared to non-compliance with the trade union demands (Quintanilla et al., 1998; Ferner and Varul, 2000; MullerCamen, 2001). In Bangladeshi context, smooth industrial relations assumed to help them in achieving their desired profitability and goals by relying on the union and CBA leaders to act in favour of the management.

Multinationals appear to recognise trade unions as useful in maintaining a clear chain of command rather than as necessary to avoid the chaotic situations, and in most cases, the trade unions act as a channel of communication between the management and the employees. In the organisational context, the legitimate power of the CBA-elected trade union leaders to bargain with the management leads the general employees to obey their advice and directions. In such a circumstance, multinational management appears to feel that it is it quite easy to convince the employees about the legitimacy of their practices through the channel of elected trade union leaders. The HR Director of B Chem pointed out that he has transferred the ex-General Secretary of the CBA into the HRM department in order to utilise his special knowledge related to labour laws and expertise in handling employee complaints as well as use him as a mediator between the management and union. Involvement of trade union leaders in the IR issues helped the MNCs to deal with the complaints of less educated production employees. The General Manager of G Pharma expressed his opinion:

"The CBA leaders are better capable of handling the illiterate unruly and aggressive union members. In the absence of any formal communication channel, union channels are used to communicate with the employees. Whenever we need to communicate anything to the general employees, we call the union leaders and ask them to inform all their fellow members."

To involve the trade union leaders in the IR issues, multinationals try to develop responsible and committed trade union leaderships in the organisations, and pursued the trade union leaders in favour of the management prerogatives. According to the General Secretary of A Pharma CBA, management provided him with the opportunity to study the Personnel Management and Industrial Relations Diploma course at Bangladesh Management Development Centre to improve his legal knowledge related to IR system. B Chem also sends trade union leaders to Industrial Relations Institutes to learn the legal framework of IR practices, and the approach proved to be beneficial in improving IR 
situations. Management find the ignorance of employees to be a main barrier in involving them in the decision-making process, although employees blame the 'high and mighty' attitude of management as the more important barrier to effective employee participation programmes (Vice President, B Chem CBA). Involvement of responsible trade union leaders may be seen as a mechanism to improve the communication channels with the general employees, and acts as a proxy to involve the employees in managerial decisions.

The trade union leaders in multinational subsidiaries also appear to co-operate with the management on different issues than those that can be seen in the local organisations. The recognition of workers' organisations for the purpose of collective bargaining depends on the relative strength of the trade unions and the organisation management. Trade union leaders in the multinationals seem to be less powerful than the power-links of the multinational organisations whose government considered as employment creators and development agents in the Bangladeshi context (Bhaskar, and Khan, 1995). It also emerges that employees are aware of capital transfer or job losses due to industrial unrest. As mentioned earlier, trade unions in Bangladesh are highly politicised and national trade union federations virtually act as the extended wings of mainstream political parties, but trade union leaders in the multinationals do not receive the same backing from the national political parties and trade union federation leaders.

In the public sector organisations, however, trade union leaders can be considered more powerful than enterprise management, and the case studies of local organisations revealed that union leaders hold the power to manipulate routine management decisions by virtue of their political links with the ruling party ministers who directly interfere in management issues with political motives. In the case study multinationals, however, trade unions leaders have little power against the management decisions, and it is difficult for them to find support from the national trade union federation leaders or main political parties in Bangladesh.

"We are in favour of trade unions in all the local and multinational organisations. The country faces a severe unemployment problem. A large number of people are working in the multinationals and receiving better wages and benefits than local organisations. Multinationals are maintaining the legal rights of trade unionism and we do not want them leaving the country for simple trade union issues. We need to think about the national interest before involving any industrial actions in the multinational organisations." (The President, National Workers Federation of Bangladesh.)

The relative power links of the multinational subsidiaries from powerful developed countries also help them to resist trade union pressures in the Bangladeshi context. In a number of instances, foreign multinationals in Bangladesh used their home country government agencies to put pressure on the government and political leaders to overcome the illegal demands of the trade union organisations, HR Director of A Pharma indicated. Foreign multinationals in Bangladesh are members of their respective foreign chambers, for instance, American multinationals are members of the American Chamber of Commerce, British multinationals are members of the British Chamber of Commerce, 
and French multinationals are members of the French Chamber of Commerce in Bangladesh, and these foreign chambers act as organised platforms for the multinationals to bargain with the government in different business-related issues. All these foreign chambers usually receive patronage or support from their respective home country diplomatic offices, and that seems to be powerful in manipulating government decisions (Kochanek, 1993) or in influencing political leaders in different ways as reported similar incidents in developed countries as well (Muller-Camen, et al., 2001).

Within the IR dynamics, the government and different IR agencies also act to promote the recognition of trade unions and the smooth operations of IR in multinational subsidiaries. The government's role in the legal arrangement of disputes resolution restricts the trade unions' capacity to initiate any industrial actions and this seems to limit unions' power and capacity to bargain with management. In the Bangladeshi context, powerful social actors can manipulate the law and justice in their favour. For example, if an unfairly terminated employee goes to the labour court for justice, it takes four to five years to receive the court verdict. It is quite impossible for a poor employee to wait such a long time and to bear the expenses of the legal procedures. Similarly if any industrial dispute is referred to the government Arbitrator or Conciliator, it takes too long to get decisions and sometimes, government officials even compel the union leaders to sit with the management for mutual discussion. In the pay bargaining process, trade unions can raise the bargaining issues for discussion, but the call for industrial action requires a legal certificate from the government arbitrator and conciliator about the failure of the dispute. After that, employers can still refer the case to the labour court which holds the ultimate power to give the final verdict of the dispute. Trade union leaders explained that most of the legal verdicts usually go in the multinationals' favour as they are more capable of handling the legal procedures in an efficient way. As mentioned earlier, national trade union federations are less likely to involve or interfere with the plant level unionmanagement bargaining process in the multinational organisations, and therefore, this also leaves them more open to powerful management initiatives. Under such circumstances, trade unions leaders in multinational subsidiaries find it beneficial to cooperate with the management and solve all the bargaining issues through mutual concessions. Recognising legal rights also helps the multinationals to avoid the interference of outsiders in organisational matters.

The legal boundaries of the collective bargaining issues seem to encourage the multinational subsidiaries to recognise trade unions and their involvement in IR activities. In fact, the legal position of plant level trade unions appears to be quite weak in the organisational context. Trade unions are legally excluded from any involvement in management decisions and their bargaining activities are restricted to only pay and benefit related issues. Plant level collective bargaining bars the outsiders from being elected as CBA representatives or trade union leaders, and restricts any influence on the bargaining process from the outside. The national trade union federation leaders maintained that plant level trade union leaders' suffers from lack of education, the limited relevant information at their disposal, their sense of job insecurity and their lack of bargaining skills, all restrict the possibility of effective bargaining at the plant level in Bangladesh (interview with national level federation leaders on 17.07.2001), and 
underscored the need to involve the federation leaders in the plant level bargaining process to fight for the legal rights of the employees. But the legislative framework prevents them from any involvement in the plant level bargaining process. In the case study multinationals, plant level trade unions in B Chem and A Pharma though maintained their relationship with the national trade union federations but received very little attention from them, in this respect, the Vice-President of CBA in B Chem commented:

"Our workers are scattered in different places. It is very difficult for us to help the political parties in the public demonstrations. We also represent quite few in number compared to public sector organisations. National trade union federations showed very little interest in us using our capacity to help them in the greater political movement."

However, the centralised pay determination process in the public sector organisations compels trade union leaders to seek outside political links to increase pressures on the government. Organisationally, plant level management does not enjoy any decision making authority in the pay and benefit issues in the public sector enterprises where trade union leaders interfere in routine management activities, and become engaged in corruption and malpractice to earn illegal money. Most of their illegal activities and their interference in management practices are carried out with the support of the incumbent political leaders who extend their support to gain political loyalty among the workers. Such political influences in the enterprise unions create inter-union and intra-union rivalry, and ultimately undermine the relationships for harmonious IR in the public sector organisations.

In fact, multinationals in Bangladesh adopted the tactic of capturing the 'heart and minds' of employees, rather than confronting or avoiding the trade unions, in order to achieve their own goals. Their strategies to gain employee loyalty seem to be effective in distracting loyalty to the wider union movement of their employees. During the British colonial and Pakistani rule periods, people held negative impressions of multinational organisations, but the multinationals in Bangladesh have developed their IR practices to overcome their previous image. They offer far better fringe benefits compared to local organisations to create a positive attitude among the employees. In a poor country like Bangladesh, employees are happy with the financial benefits which they value over work autonomy or decision-making involvement. The unequal power gap between the union and the management, and the legally weak position of trade unions has placed management in an advantageous position to entice the employees towards management alignment.

\section{Withered parent company practices}

In the case study multinational subsidiaries, IR practices appear to have been left to the host country management without any influence from the HQ. The parent companies have delegated all responsibilities to local management regarding the IR matters, but it seems that multinational subsidiaries operating as part of an integrated production 
network are more conscious than those local market-serving subsidiaries and this might be due to the implicit direction of the parent company to ensure uninterrupted production facilities at the plant. Now N Pharma, A Pharma, and B Chem are exporting to other countries and industrial disputes might interrupt their business in other countries. As the subsidiaries became part of an integrated production network, HQ is beginning to ask them to comply with all legal requirements for the sack of uninterrupted production flows. Now the HQ has delegated all the responsibilities to the local HR department to handle all the employee relations activities in an efficient way. Multinationals recognise the importance of local knowledge for smooth IR practices, and provide more resources to the personnel function than do local market-serving organisations. All the exportoriented multinational subsidiaries have upgraded the position of the head of the HR department, and expanded the role of the HR department in the national executive management committees.

While investigating the parent company influences on subsidiaries' IR practices, we also tried to identify the dissemination of HQ specified practices in the Bangladeshi context but it seems that none of them has initiated any distinctive IR practices with instructions from the HQs. The Bangladeshi contexts might discourage the multinational subsidiaries from initiating such practices in the subsidiaries. The ex-General Manager of B Chem explained his experience of introducing employee suggestion schemes in Bangladesh.

"Once I attended in a management development training programme in the UK. The usefulness of an employee involvement practices in the decision making process was demonstrated. After returning from the training, I initiated an employee suggestion scheme to improve the production process. But it emerged that employees failed to understand the actual theme of the schemes, and brought all their personal and irrelevant extra-organisational matters to the management. Later on, we abandoned the scheme."

We also investigated whether multinational subsidiaries have shown any support for the establishment of 'works councils', 'participation committees', or any other employee involvement schemes as seen in many developed countries, where HQs encourage such employee participation initiatives in the decision making process. However, there was no sign of any such initiatives in the multinational subsidiaries in Bangladesh, nor did these companies' even try to form any association or platform to influence the government to arrange sector level bargaining. Foreign multinationals in Bangladesh, although they joined different foreign chambers to raise their voice to the government and other concerned bodies, used those platforms in the union-management collective bargaining at the organisational matters.

\section{Not complying with all the issues: slow transformation on the way}

Although it seems that multinationals in Bangladesh are abiding by the legal requirements in their IR practices, some critical observations revealed transformation of the traditional practices in the case study multinational subsidiaries. As long as the legal framework serves their purposes, they seem not to confront to the trade union practices, 
but whenever they face any legal requirements that act against their interest, they try to push back or bring about a slow transformation of traditional practices by using their prudent practices.

In the absence of rule of law, employees depend on the unions to raise their voice against all perceived unfair actions, and in many cases, unions play the role of the pressure group that management takes into account before making any unilateral decisions. However, multinationals are carefully implementing practices that undermine the traditional bases of union power, because traditionally, individual employee grievances or complaints are settled through the trade union channel. But multinationals are delegating the personnel role to the line managers and asking the departmental heads to solve all the problems without any union involvement. Routine arrangements of CBA elections and pay bargaining meetings in the case study multinational subsidiaries motivate the employees to be loyal and more sympathetic to the management, rather than biased toward the union leaders. The HR Director of N Pharma explains the delegation of responsibilities to the line managers as being to undermine the union involvement in IR issues.

"Earlier there were 10 employees working in the Personnel Department. Now only three of us are working in this department. We delegated all the responsibilities to the line managers to solve the individual problems. We also included managerial skills in the performance evaluation criteria. We, the Human Resource Department, rarely need to involve in employee grievance or disputes issues."

Multinationals are also weakening union power by employing part-time and contract employees. Local public sector organisations never use part-time or agency employees, but multinationals are employing a large number of agency employees in their auxiliary work which trade union leaders indicated as an attempt to keep unionisation at the lowest level. Legal provisions do not allow for part-time and contract employees to join trade unions and multinationals offer less benefit to those employees. It may also be the case, that permanent employees are offered better conditions at the expense of part-time employees' privileges and rights. Multinationals in Bangladesh have also upgraded the clerical/nonmanagerial posts to managerial posts by changing the job titles of clerical/secretarial employees and restricting their eligibility to join trade unions. This symbolic upgrade of posts has reduced the trade union members to the lowest possible number as well as created barriers in developing capable trade union leadership at the plant level who can effectively bargain with the management. It may be worth reiterating that in the Bangladeshi society, clerical/secretarial jobs carry more weight and are more valued than production jobs, and clerical/secretarial employees need to have better educational qualifications compared to production employees (Selim, 1998). The QA officer in N Pharma pointed out that multinational pharmaceuticals and other consumer goodsproducing organisations have changed the job title of their medical representatives to the title of 'medical promotion officers' and thus avoid unionisation of their sales employees. Similarly, all the foreign banks in Bangladesh have changed the job title of clerical employees/cashiers to the title of 'cash officer' or 'junior officer' to prevent them from joining the trade unions. 
Multinational subsidiaries have also tried to develop individualised pay and benefits packages for non-managerial employees, but the legal context of pay bargaining with the CBA representatives has compelled them to abandon the attempt as CBA leaders disagreed with accepting such individualisation of effort for non-managerial employees. However, the multinational subsidiaries are still trying to introduce some elements of an individualised pay package for the non-managerial employees. In addition to fixed rate annual increments and equal bonuses, they offer special bonuses or increments to extraordinary performers in an effort to bring about some form of individualised benefits among the employees. The HR Director of N Pharam expressed his optimism that he would be able to change trade union attitudes in the near future in favour of such individualised pay and benefit practices. Although our case study multinational subsidiaries recognise trade unions for collective bargaining purposes, they nevertheless try to keep the union influences at the lowest possible level. To avoid problems arising from the presence of multiple unions, multinationals adopt a policy of avoiding the formation of multiple unions or any links to national trade union federations. None of the case study multinational subsidiaries have more than two trade unions, although legally, employees can form up to three trade unions in any single plant or establishment.

\section{Conclusion}

It seems that the findings support the 'compliance thesis' (Wever, 1995) instead of 'divergence-convergence theses' with regard to union recognition, collective bargaining, and IR practices more than the union avoidance strategy that has been cited in most of the international HRM literature. The adversarial relations in the local organisations are the results of the avoidance strategy of the management, management support to a particular union, personal interests of managerial staff and workers, inter-union and intra-union rivalries, politicisation of trade unions, and management inefficiency in handling the IR issues. But multinational subsidiaries in Bangladesh are able to overcome such problems with their efficient HR practices and by adopting the legally-specified practices to avail themselves of the opportunities presented by the less regulated institutional context of Bangladesh. Nevertheless, their compliance could be relatively superficial and the subsidiaries are adopting a range of strategies indirectly to avoid influences on managerial practices, while at the same time recognising trade unions in the interests of the management of the wider workforce. This compliance could be seen as the 'country of origin' effects for the multinationals as our case study organizations are of European and American origins where parent company country IR system itself also very much fluid and dynamic to adjust with the contemporary market imperatives and technological influences (Clark and Almond, 2004).

However, in recent years, an attitudinal change towards workers and trade unions has occurred in private sector organisations, and in several instances, employers have taken initiatives to resolve the industrial disputes, enabling both the unions and management to cooperate with each other at the plant or sector level and avoiding government intervention. Employers and employees both termed this as a welcome step, because the tripartite nature of the conflict resolving process seems to be ineffective purely due to government involvement with prior political motives. The bipartite dispute resolving mechanism in the Garment and 
Leather sector seems to be a good example of an effective industrial relations process in the Bangladeshi context, and the Bangladesh Garments Manufacturers and Exporters Association (BGMEA) established a conciliation-cum-arbitration committee consisting of a Chief Arbitrator and 18 members with equal representation from the BGMEA and the labour organisations in the sector. As of February 2000, 75 percent of all reported cases were resolved, and the remaining ones were only unresolved due to contingencies such as the death or migration of the plaintiff or the absence of either party at the hearing because of illness or preoccupation with other commitments. In the leather sector, Bangladesh Finished Leather, Leather Goods, and Footwear Exporters' Association executive committees and the trade unions meet every two years to discuss workers' and employees' grievances. Through mutual consultations and understanding, they have resolved all kinds of disputes reflecting amity between workers and employees (Mondal, 2001).

\section{References}

Ahmad, M. (1989), Transnational Corporations from Asian and Pacific Developing Economies in Bangladesh, Bangladesh Journal of Political Economy, Vol.19, No. 2, pp. 340-384.

Ahmad, M. (1998), Education and Governance in Bangladesh, in Sobhan, R. (eds.) Crisis in Governance: A Review of Bangladesh's Development 1997, Dhaka: University Press Ltd.

Ahmed, S. (1993), Measures to increase the contribution of vocational training for employment generation and poverty alleviation: experience of BRAC, paper presented at the national seminar on Role of Vocational Training towards Human Resource Development in Bangladesh, Dhaka: 17-20 July.

Ahmed, M. and Mondal, A. (1993), Structural adjustment, labour market reforms, industrial relations and productivity in Bangladesh, in Social Dimensions of Economic Reforms in Bangladesh, proceedings of the National Tripartite Workshop held in Dhaka, Bangladesh, 18-20 May, ILO-ARTEP.

Akkas, M. A. (1998), Labour-Management Co-operation: The Bangladesh Perspectives, Dhaka University Journal of Business Studies, Vol. 19, No. 2, pp. 117-145.

Alam, F. (1983), Industrial dispute laws in Bangladesh: A study in their development perspectives, The Personnel, Vol. 3, pp. 61-93.

Bhuiyan, M.S. (2001), The Transferability of Japanese Management in Bangladesh: Does Culture Matter?, Journal of Development Alternatives and Area Studies, Vol. 20, No. 2\&3, pp. 5-27.

Bhaskar, V. and Khan, M. (1995), Privatisation and Employment: A Study of the Jute Industry in Bangladesh, The American Economic Review, Vol. 85, No. 1.

Chowdhury, M., Anwar, A. and Masum, M. (1998), Performance of Foreign Banks vis-à-vis Other Commercial Banks Operating in Bangladesh, Dhaka University Journal of Business Studies, Vol. 19, No. 2, pp. 117-145.

Clark, I. and Almond, P. (2004), Dynamism and Embeddedness: Towards a Lower Road? British Subsidiaries of American Multinationals, Industrial Relations Journal, Vol. 35, No. 6, pp. 536-556.

Clark, I. and Mueller, F. (1996), Organisations and Nations: from Universalism to Institutionalism?, British Journal of Management, Vol. 7, pp.125-139. 
Cleveland, J., Gunnigle, P., Heraty, N. Morely, M. and Murphy, K (2000), US Multinationals and Human Resource Management: Evidence on HR Practices in European Subsidiaries, Irish Business and Administrative Research, Vol. 21, pp. 9-27.

Coller, X. and Marginson, P. (1998), Channels of Influences over Employment Practice in MNCs: A Case from the Food Industry, Industrial Relations Journal, Vol. 29, No. 1, pp. 4-17.

Colling, T. and Clark, I. (2002), Looking for 'Americanness': Home-country, sector and firm effects of employment systems in an engineering service company, European Industrial Relations Journal, Vol. 3, pp. 234-246.

Dickman, M. (1999), Balancing Global, Parent and Local Influences: International Human Resource Management of German Multinational Companies, unpublished Ph D thesis, Birkbeck College, University of London, UK.

Edwards, T. (1998), Multinationals, labour management and the process of reverse diffusion: A case study, International Journal of Human Resource Management, Vol. 9, No.4, pp.696-709.

Edwards, T. (2000), Multinationals, International Integration and Employment Practice in Domestic Plants, Industrial Relations Journal, Vol. 31, No. 2, pp. 115-129.

Edwards, T. (2004), The transfer of employment practices across borders in multinational companies, in Harzing, A. and Ruysseveldt, J. (eds.) International Human Resource Management, London: Sage Publications.

Edwards, T. and Ferner, A. (2002), The Renewed "American Challenge": A Framework for Understanding Employment Practice in US Multinationals, Industrial Relations Journal, Vol. 33, No. 2, 94-111.

Ferner, A. and Varul, M. (2000), Internationalisation and the Personnel Function in German Multinationals, Human Resource Management Journal, Vol. 10, No. 3, pp. 79-96.

Hossain, I. (2001), Export processing zones in Bangladesh and industrial relations, report on 'social impact on globalisation: role of policy, Dhaka: ILO.

Hossain, M., Hye, S. and Ali, M. (1998), Structural Adjustment Policies and Labour Market in Bangladesh, MAP Focus Study Series No. 5, Dhaka:CIRDAP.

Hoque, K. B. (1994), Management System in Bangladesh and Japan: A Comparative Study, Institute of Developing Economies, VFR Monograp Series No. 23, Tokyo.

Khan, M. N. (1996), Labour Administration: Profile on Bangladesh, International Labour Organisation Area Office, Dhaka: Bangladesh.

Miles, M. and Huberman, A. (1994), Qualitative Data Analysis, Thousand Oaks: SAGE Publications.

Mondal, A. (1992), Trade unionism, wages and labour productivity in the manufacturing sector of Bangladesh, Research Report No. 133, Bangladesh Institute of Development Studies, Dhaka.

Mondal, A. (1992), Globalisation, industrial relations, and labour policies: A renewed agenda for social dialogue in Bangladesh, Dhaka: ILO country office.

Monks, K. (1996), Global or Local?-HRM in the Multinational Company: The Irish Experience, International Journal of Human Resource Management, Vol. 7, No. 3, pp. 721-735.

Muller, M. (1998), Human Resource and Industrial Relations Practices of UK and US Multinationals in Germany, International Journal of Human Resource Management, Vol. 9, No. 4, pp. 732-749. 
Muller-Camen, M., Almond, P., Gunnigle, P., Quintanilla, J. and Tempel, A. (2001), Between Home and Host Country: Multinationals and Employment Relations in Europe, Industrial Relations Journal, Vol. 32, No. 5, pp. 435-448.

Quintanilla, J. (1998), The configuration of Human Resource Management Policies and Practices in Multinational Subsidiaries: The Case of European Retail Banks in Spain, unpublished Ph D thesis, Warwick Business School, The University of Warwick.

Rahman, M. (1994), Structural Adjustment, Employment and Workers: Public Policy Issues and Choices for Bangladesh, Dhaka: University Press Ltd.

Selim, M. (1995), The Experience of a Multinational Company in Bangladesh, ICBAS, Dhaka and ORSTOM, Paris.

Taher, M. (1999), Politicisation of trade unions: Issues and challenges in Bangladesh perspective, Indian Journal of Industrial Relations, Vol. 34, No. 4, pp. 403-420.

Taher, M., Zaman, M, and Mahmood, M. (1998), Multiplicity of Trade Unions in Bangladesh: The Case of Chittagong Port Authority, Journal of Business, Vol.1, No. 3.

Talukdar, M. (1996), Labour and Industry, Dhaka: Nasa Publishers.

Wever, K. (1995), Negotiating Competitiveness, Employment Relations and Industrial Adjustment in the US and Germany, Boston, MA: Harvard Business School Press.

Whitfield, K. and Strauss, G. (2000), Methods Matter: Changes in Industrial Relations Research and Their Implications, British Journal of Industrial Relations, Vol. 38, No. 1, pp.141-151. 